\title{
Mutational Screening of BRCA1/2 Genes as a Predictive Factor for Therapeutic Response in Epithelial Ovarian Cancer: A Consensus Guide from the Spanish Society of Pathology (SEAP-IAP) and the Spanish Society of Human Genetics (AEGH)
}

\author{
J. Palacios ${ }^{1,2,3,4}$ (iD - M. de la Hoya ${ }^{4,5}$ - B. Bellosillo ${ }^{4,6}$ - I. de Juan ${ }^{7}$ • X. Matías-Guiu ${ }^{4,8}$ - C. Lázaro ${ }^{4,9} \cdot$ S. Palanca $^{7}$. \\ A. Osorio ${ }^{10,11} \cdot$ F. Rojo ${ }^{4,12}$ - J.M. Rosa-Rosa ${ }^{2,4}$ • J.C. Cigudosa ${ }^{13}$
}

Received: 30 August 2019 / Revised: 11 October 2019 / Accepted: 25 October 2019 / Published online: 3 December 2019

(C) The Author(s) 2019

\begin{abstract}
Germline/somatic BRCA-mutated ovarian carcinomas (OC) are associated to have better response with platinum-based chemotherapy and long-term prognosis than non-BRCA-associated OCs. In addition, these mutations are predictive factors to response to Poly(ADP-ribose) polymerase (PARP) inhibitors. Different positioning papers have addressed the clinical recommendations for BRCA testing in OC. This consensus guide represents a collection of technical recommendations to address the detection of BRCA1/2 mutations in the molecular diagnostic testing strategy for OC. Under the coordination of Spanish Society of Pathology (SEAP-IAP) and the Spanish Society of Human Genetics (AEGH), these recommendations have been developed by pathologists and geneticists taking into account previously published recommendations and their experience in the molecular characterization of these genes. Since the implementation of $B R C A$ testing as a predictive factor can initiate the workflow by testing germline mutations in the blood or by testing both germline and somatic mutations in tumor tissue, distinctive features of both strategies are discussed. Additionally, the recommendations included in this paper provide some references, quality parameters, and genomic tools aimed to standardize and facilitate the clinical genomic diagnosis of OC.
\end{abstract}

Keywords BRCA · Next-generation sequencing (NGS) • Ovarian cancer (OC)

This article is part of the Topical Collection on Quality in Pathology

J. Palacios

jose.palacios@salud.madrid.org

1 Servicio de Anatomía Patológica, Hospital Universitario Ramón y Cajal, 28034 Madrid, Spain

2 Instituto Ramón y Cajal de Investigación Sanitaria, 28034 Madrid, Spain

3 Universidad de Alcalá, 28801 Alcalá de Henares, Spain

4 CIBER-ONC, Instituto de Salud Carlos III, 28029 Madrid, Spain

5 Molecular Oncology Laboratory, Hospital Clinico San Carlos, IdISSC (Instituto de Investigación Sanitaria del Hospital Clínico San Carlos), Madrid, Spain

6 Laboratorio de Diagnóstico Molecular, Servicio de Patología, Hospital del Mar, 08003 Barcelona, Spain
7 Unidad de Biología Molecular, Servicio de Análisis Clínicos, Hospital Universitario y Politécnico La Fe, 46026 Valencia, Spain

8 Servicio de Anatomía Patológica, Hospital Universitario de Bellvitge, 08908 L'Hospitalet, Spain

9 Unidad de Diagnóstico Molecular, Institut Català d'Oncologia, (ICO-IDIBELL-ONCOBELL), 08908 L'Hospitalet, Spain

10 Human Cancer Genetics Programme, Spanish National Cancer Centre (CNIO), 28029 Madrid, Spain

11 CIBER-ER, Instituto de Salud Carlos III, 28029 Madrid, Spain

12 Departamento de Patología, Fundación Jímenez-Díaz, 28040 Madrid, Spain

13 NIMGenetics, Parque Científico de Madrid, Campus Cantoblanco, 28049 Madrid, Spain 


\section{Introduction}

Ovarian cancer (OC), the most aggressive gynecologic malignancy, produced 42,704 deaths in Europe in 2012 (1). This high lethality can be attributed, among other factors, to its frequent late stage at presentation and limited treatment options. $\mathrm{OC}$ is a heterogeneous disease that includes five main histological types [53]: high-grade serous carcinoma (HGSC), low-grade serous carcinoma (LGSC), endometrioid carcinoma (EOC), clear cell carcinoma (CCC), and mucinous carcinoma (MC). These histological subtypes have different epidemiological and genetic risk factors, and they differ also with respect to precursor lesions, pattern of tumor spread, prognosis, and response to common therapy approaches, such as chemotherapy, hormone therapy or poly(ADP-ribose) polymerase (PARP) inhibitors (PARPi) [44]. For example, HGSC, representing $70 \%$ of late-stage tumors, is associated in some cases with a specific precursor lesion (serous intraepithelial carcinoma of the fallopian tube), and has a poor prognosis, even though approximately $50 \%$ of the patients show an initial good response to platinum therapy. From a molecular point of view, approximately $95 \%$ of HGSC carry TP53 mutations and about 50\% have homologous recombination deficiency (HRD) due to alterations in genes involved in the homologous recombination DNA repair pathway [63].

In the TCGA cohort, $20 \%$ of HGSC carried mutations in BRCA genes: $9 \%$ germline mutations in BRCA1, $8 \%$ germline mutations in BRCA2, and $3 \%$ somatic mutations affecting one of the two genes [63]. In addition, $B R C A 1 / 2$ mutations (both somatic and germline) have been reported in $15 \%$ and $10 \%$ of EOC and CCC, respectively [51].

Identification of $B R C A$-mutated OC patients is important for the following reasons:

- To identify BRCA germline mutation carriers ( $40 \%$ of patients with $\mathrm{OC}$ and pathogenic germline $B R C A 1 / 2$ variants have no family history of breast or ovarian cancer).

- Germline/somatic BRCA-mutated OCs are associated with better response to platinum-based chemotherapy (the standard of care in patients with late-stage $\mathrm{OC}$ ) and long-term prognosis than non- $B R C A$-associated OCs.

- Germline/somatic BRCA mutation is a predictive factor to response to PARPi.

Current recommendations for BRCA testing vary among European countries. Thus, Vergote et al. [66] observed differences regarding testing criteria based on the histology of the tumors. Testing was offered for all ovarian cancers in the Netherlands, Italy, Scotland, and the Czech Republic, for all non-mucinous high-grade carcinomas in France and for all high-grade serous carcinomas in Germany, Belgium, and
Portugal. Recently the ESMO-ESGO consensus conference recommended testing for $B R C A 1 / 2$ mutations for all patients with non-mucinous ovarian cancer [15].

In Spain, a national consensus issued by the Spanish Society of Pathology (SEAP-IAP) and the Spanish Society of Medical Oncology (SEOM) recommended that germline $B R C A 1 / 2$ mutation testing should be offered to all patients with high-grade non-mucinous ovarian carcinomas. In addition, somatic testing should be considered in cases negative for germline mutations. At present, although the consensus recognizes the potential role of testing other HRD genes, its clinical implementation is still low [49].

Provided that the clinical recommendations have been addressed by different positioning papers [31, 49, 66], our consensus guide represents a collection of technical recommendations to address the detection of BRCA1/2 mutations in the molecular diagnostic testing strategy for OC. Under the coordination of Spanish Society of Pathology (SEAP-IAP) and the Spanish Society of Human Genetics (AEGH), these recommendations have been developed by pathologists and geneticists taking into account previously published recommendations [19] and their experience in the molecular characterization of these genes.

An important question regarding the implementation of $B R C A$ testing as a predictive factor is whether to initiate the workflow by testing germline mutations in the blood or by testing both germline and somatic mutations in tumor tissue. Distinctive features of both strategies are summarized in Table 1. Additionally, the recommendations included in this paper provide some references, quality parameters, and genomic tools aimed to standardize and facilitate the clinical genomic diagnosis of OC.

\section{Pre-analytical Considerations}

Any pre-analytical factor that modifies the quality of the sample could potentially impact in the results [29, 33]. A recent publication has reviewed pathology practices to ensure molecular integrity biospecimens for precision medicine [17]. The labeling, preparation, and formaldehyde fixation (if necessary) and the delivery to the laboratory in which the study is performed are the responsibilities of the professional in charge of obtaining the sample. The laboratory performing the molecular study must be able to handle different types of samples. The key recommendation in pre-analytical process in both tissue and blood samples are summarized in Table 2.

Briefly, in tissue samples, the cold ischemia time (Cit), the period of time since tissue is obtained and its fixation, impacts on DNA, RNA, and proteins in large surgery specimens, like ovary tumors [6]. To limit this effect, standard procedures in tissue preservation in fixative process or freezing in optimum cutting temperature (OCT) compound are recommended for optimum DNA recovery. However, DNA is more frequently isolated from formalin-fixed paraffin-embedded (FFPE) samples and is highly 
Table 1 Characteristics to take into account of the BRCA testing on blood and tumor samples

\begin{tabular}{|c|c|c|}
\hline & Blood BRCA testing & Tumor BRCA testing \\
\hline Pre-analytical considerations & Pre-analytical conditions less critical & Risk of delayed fixation and overfixation \\
\hline \multirow[t]{6}{*}{ Analytical phase $N G S$} & Detection of germline mutations & Detection of germline and somatic mutations \\
\hline & $\begin{array}{l}\text { Methods must detect at least } \geq 50 \% \\
\text { variant allele frequency }\end{array}$ & $\begin{array}{l}\text { Methods must detect at least } \geq 5-10 \% \\
\text { variant allele frequency }\end{array}$ \\
\hline & $\begin{array}{l}\text { Recommended average sequencing } \\
\text { coverage between } 50 \times-250 \times \text { reads }\end{array}$ & $\begin{array}{l}\text { Recommended average sequencing coverage between } \\
500 \times-2000 \times \text { reads }\end{array}$ \\
\hline & Possible to detect large deletions/rearrangements & Difficult to detect large deletions/rearrangements \\
\hline & Unlikely to generate false-positive SNVs & Fixation artifacts/generation of false-positive SNVs \\
\hline & Well-established validated NGS methods & Not fully available validated NGS methods \\
\hline \multirow[t]{4}{*}{ Post-analytical phase $N G S$ (I) } & Straightforward analysis & Complex analysis \\
\hline & Simple and validated filter pipelines & More complex. Sensitive to filtering methods \\
\hline & \multirow{2}{*}{$\begin{array}{l}\text { Heterozygous pathogenic } \\
\quad \text { variants }(\mathrm{VAF}=50 \%)\end{array}$} & Heterozygous pathogenic variants (VAF $<50 \%$ ) \\
\hline & & False-negative results $(\mathrm{VAF}<5-10 \%)$ \\
\hline \multirow[t]{3}{*}{ Post-analytical phase $N G S$ (II) } & $\begin{array}{l}\text { Possibility to miss a group of patients } \\
\quad(<10 \%) \text { that could benefit for PARPi therapy }\end{array}$ & $\begin{array}{l}\text { Identification all possible patients that can benefit } \\
\text { for PARPi therapy based on } B R C A \text { testing }\end{array}$ \\
\hline & \multirow[t]{2}{*}{$\begin{array}{l}\text { Low percentage of VUS expected } \\
\qquad(<10 \% \text { in a well characterized population) }\end{array}$} & $\begin{array}{l}\text { Possibility of finding novel variants for which there is } \\
\text { no information in databases and increase the \% of VUS }\end{array}$ \\
\hline & & $\begin{array}{l}\text { More information needs to be included in the report } \\
\text { which makes it more laborious }\end{array}$ \\
\hline
\end{tabular}

recommended that the tissue fixation procedure be controlled by the pathology laboratory $[18,59,68][57,61][22]$. Finally, morphological diagnosis should always include the type and grade of the tumors in order to gain insight into genotypic/phenotypic correlations. Representative tumor area selection and percentage of malignant cells must be performed by a well-trained pathologist on an $\mathrm{H} \& \mathrm{E}$ section. A minimum of $30 \%$ of tumor cellularity is recommended to guarantee the detection of a variant through molecular techniques [21].

Blood samples should be collected in tubes with either EDTA or nucleic acids preserving agents, and processed immediately after its extraction, ideally in less than 30 min when tubes contain no preservatives [36] and following standard procedures. The leucocyte fraction is an excellent source for the study of germline DNA, being the standard nowadays. The serum contains DNA from leucocytes, in worse preservation conditions, and the plasma contains circulating free DNA. However, the study of germline mutations can be performed using also whole blood without fraction separation.

DNA extraction based on precipitation, magnetic beads, or silica-based membrane columns shows similar efficiency upon quality and concentration of the DNA obtained [42]. However, it is highly recommended that DNA extraction is standardized and performed using CE-IVD marking techniques in both manual and automatized processes. These processes must be performed strictly following the manufacturer's guidelines and standardized procedures after a privative validation process prior to the clinical use [10].
Measures for assuring full traceability of the sample and its derived products to avoid cross-contamination are critical. For tissue samples, precautions such as the preparation of free nucleic acid plastic containers, the use of PCR quality water for floating baths, and the systematic cleaning of devices with DNA and RNA removers [20] should be taken.

The use of spectrophotometry (Nanodrop), fluorometry (Qubit), and/or PCR fragment (Agilent Bioanalyzer) systems is recommended for the quantification and qualification of the DNA obtained, especially in tissue sample where formaldehyde and paraffin treatments produce the fragmentation of the DNA [42]. Isolated DNA must be kept at $-20{ }^{\circ} \mathrm{C}$, while PCR products and library prepared should be kept in a different freezer at -20 or $-80{ }^{\circ} \mathrm{C}$ to avoid cross-contamination. There is not a large amount of information about the impact of the storage time on the quality of the DNA or amplification products, but, in general, their stability is assumed for several years [43].

\section{Analytical Phase: Next-Generation Sequencing (NGS)}

Library preparation adapts the nucleic acids to be sequenced, including the fragmentation of the DNA by either physical (sonication) or enzymatic (endonuclease cocktail or transposase-mediated fragmentation) methods, adapter linkage, and the enrichment of the regions of interest (ROI). There are several strategies for ROI enrichment, and differences should be taken into account prior to the sequencing process. Ampliconbased methods are characterized by shortened and simplified 
Table 2 Pre-analytical recommendations for $B R C A$ testing

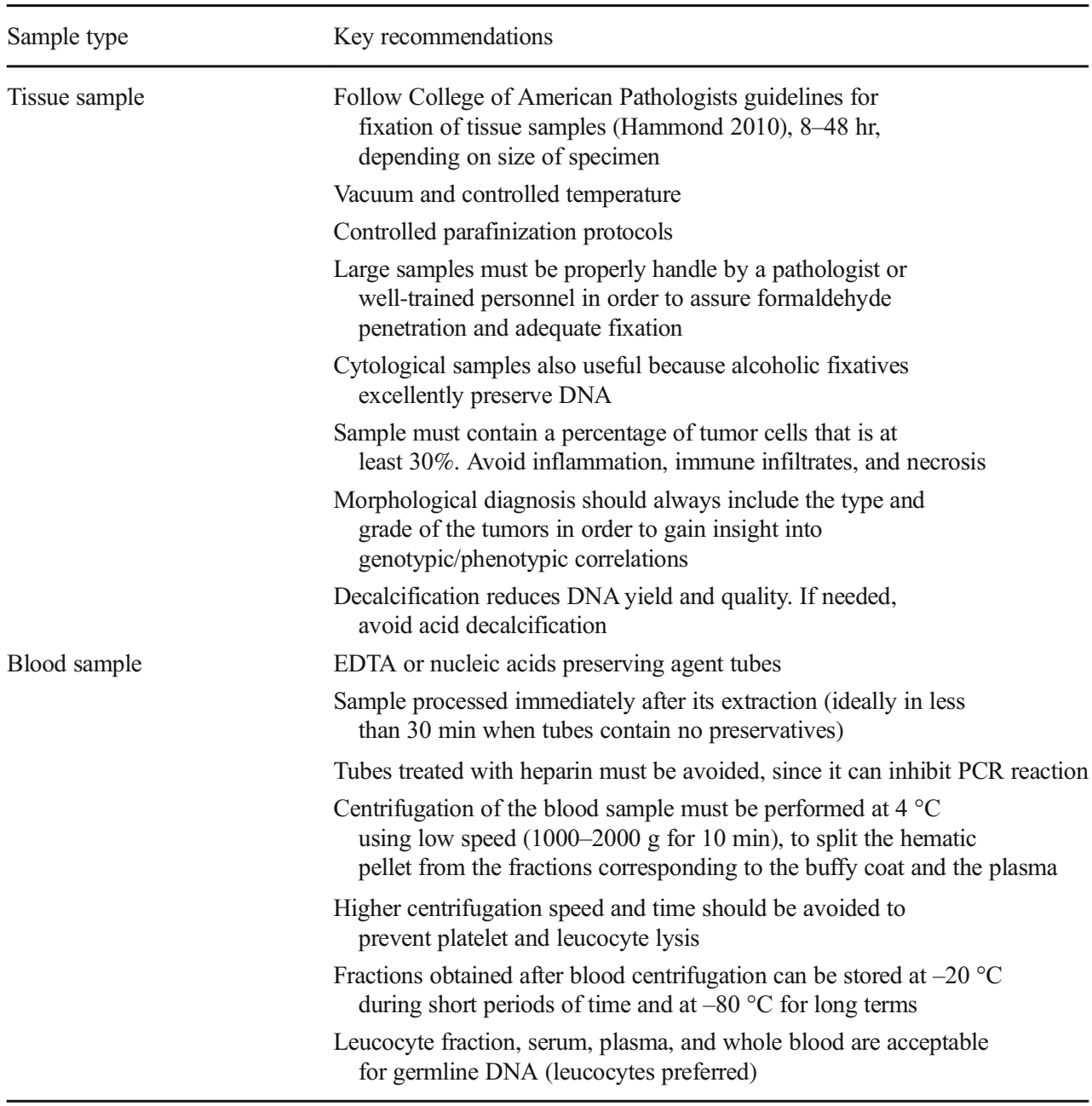

preparation protocols also requiring smaller DNA inputs and no fragmentation step. This is especially relevant when working with small FFPE clinical specimens. This technology provides higher on-target values, while hybridization capture-based methods demonstrated higher uniformity rate. However both approaches have demonstrated technical and clinical utility in diagnostic procedures [56].

Molecular barcodes are introduced to allow sample identification and combination in a unique sequencing reaction [32]. After library preparation, appropriated quality control steps should be performed to determine the feasibility of the sample to continue the procedures. These quality control steps include quantification of the library, size analysis of the fragments, and quantitative PCR using adapter to check the real amplifiability of the library fragments.

The combination of sequencing platforms and commercially available sequencing kits offers a variety of options for nextgeneration sequencing (NGS) studies [9, 30, 37]. However, it is important to acknowledge that cost efficiency and acceptable turnaround times will only be achieved by fully exploiting the capacity of the sequencing runs, so sequencing strategy should be chosen based on the laboratory NGS testing demand [58]. In this regard, the use of commercially available panels (see Table 3) for BRCA1/2 testing is the most common praxis in clinical routine. Since they have been validated by the manufacturers, their implementation has turned out to be easier. BRCA1/2 genes are included in several NGS panels, such as BRCA panels in which only these genes are tested, hereditary cancer panels including other cancer-predisposing genes, and somatic cancer panels designed to detect oncogenic mechanisms in FFPE samples.

In conclusion, the choice of the NGS panel for library preparation will depend on the type of study (somatic, germinal, or both) and the sequencing strategy available in the institution [56]. A good NGS testing strategy of BRCA1/2 genes should allow the identification of single nucleotide variants (SNVs) and small insertions-deletions (indels) in all coding exons and exon-intron boundaries, as well as CNVs, although the latest can be determined by other techniques such as multiplex ligation-dependent probe amplification (MLPA). 


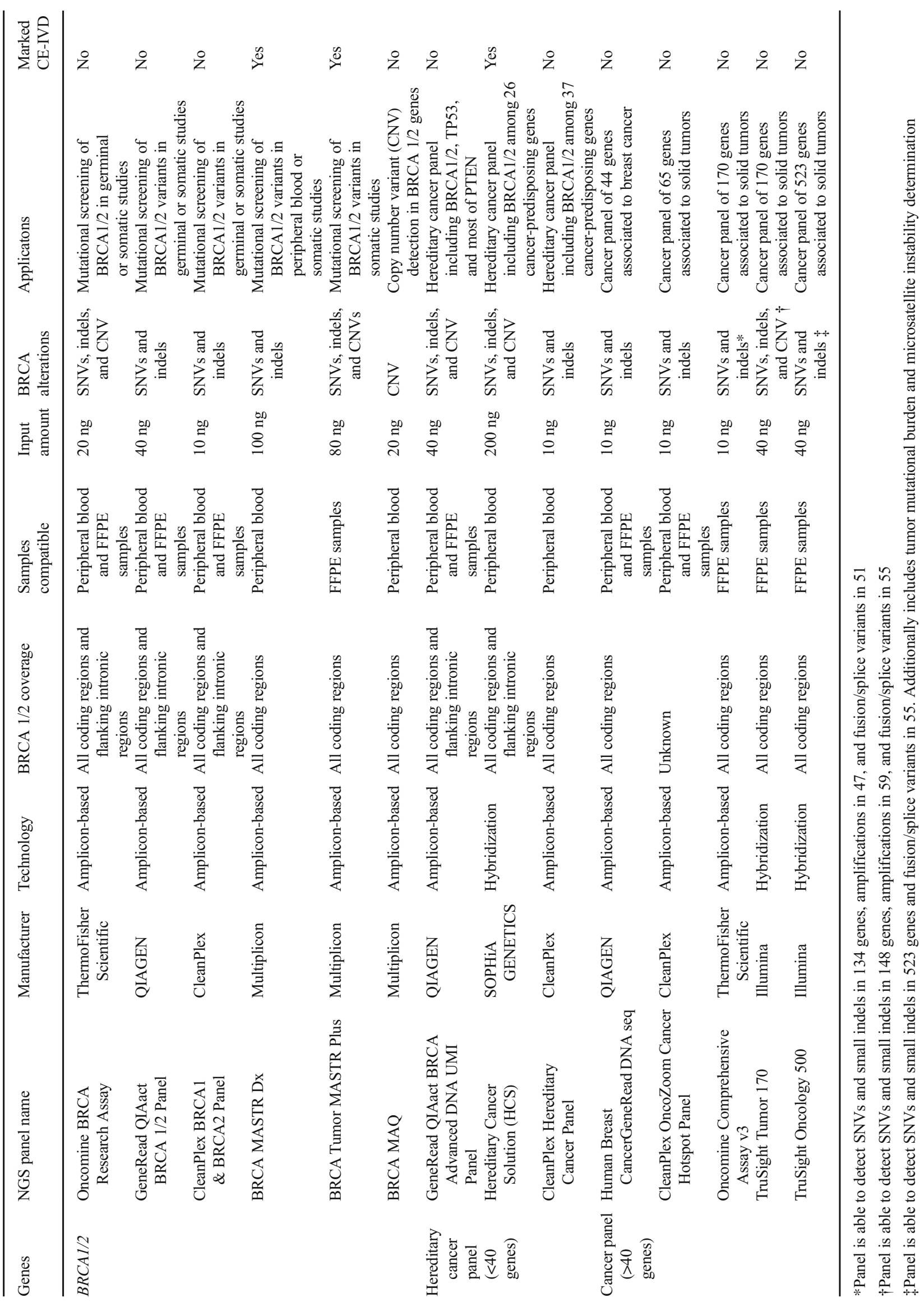




\section{Post-analytical Phase I: Analysis and Filtering of Variants}

Data analysis is performed after the sequencing process and can be divided into three stages: primary, secondary, and tertiary analysis. The primary analysis consists of base calling and demultiplexing processes and is performed automatically by specific software on the sequencer. Base calling is the conversion of raw data to nucleotide reads, and the demultiplexing process separates data from each sample according to specific barcodes. A quality control of the run is also performed at this stage by the technical staff to verify the amount of the library pool loaded as well as the general sequencing process. Although there are different file formats to store primary analysis results, FASTQ and BAM are the most commonly used.

The secondary analysis can be done on the same sequencer or employing external pipelines or workflows [26]. Quality control of each sample reads; elimination of low-quality reads, adapters, primers, and duplicated reads; and alignment are the basic processes along this step. During the alignment step, each read is compared against the reference sequence of the human genome to locate its original position, which can be improved using the distance and orientation of paired-end reads [50]. The most widely used mapping file format is the Sequence Alignment Map (SAM) and its compressed version Binary Alignment Map (BAM) [55]. Depending on the enrichment technique used for library preparation, after the initial mapping, duplicate reads might be removed to avoid false-positive variant calls due to unwanted clonal amplification of reads with sequence artifacts. Duplicate reads can be eliminated based on the genomic position or because they share a UMI (unique molecular identifiers). The addition of UMIs before PCR amplification discriminates between alleles arising from the same genomic locus and sequencing reads produced by PCR amplification [13]. After alignment, genome browsers, like the Integrative Genomics Viewer (IGV), propose the majority or highest-quality base for each position [41]. Finally, reads can be recalibrated, and the indels realigned, by consensus, to the left [55]. Variant calling is the step where the variants (bases that differ from the reference genome) are identified for each sample. Variant calling format (VCF) is the standard file to store the information of variants (one line per variant). The variant information from different individuals can be stored in a single VCF file. Variant filtering criteria vary depending on the NGS platform and the enrichment system used, like the minimum number of reads covering the base, as well as the minimum average coverage and depth accepted for a variant. In the case of tumor samples, the variant allele frequency (VAF) varies in function of the tumoral cellularity present in the sample and the tumor proportion with the alteration [50] (the minimum average read depth to detect variants with a VAF of $5 \%$ should be 500X). An accurate filtering increases the quality of the results, e.g., filtering out reads with a quality value $<\mathrm{Q} 30$ can greatly improve the dataset, as quality score of 30 represents an error rate of 1 in
$1000 \mathrm{X}$ [55] with a corresponding call accuracy of $99.9 \%$. In BRCA1/2 the most frequent variants observed are single nucleotide polymorphisms (SNPs), indels, single nucleotide variants (SNVs), and copy number variations (CNVs) [50]. One limitation of current NGS approaches is the ability to reliably detect CNVs, since NGS mainly depends on the panel employed and the quality of the DNA samples. In somatic test, the high heterogeneity increases the background noise in the CNV copy plot, leading to frequent false results. Several bioinformatics tools for CNV assessment have been developed [38].

The tertiary analysis consists of the functional annotation of the variants identified in the individuals and the selection of pathogenic variants (see post-analytical phase II section). In this stage, the technical and biological information is integrated to interpret the variants detected through the sequencing process $[50,55]$.

Data analysis is the most complex and time-consuming stage of the entire NGS process; therefore, qualified personnel are required, either a geneticist or a molecular biologist appropriately trained to handle the complex classification of genetic variants across BRCA genes. In case of somatic mutation analysis, the importance of the pathologist expertise is stressed, since the impact of pre-analytical conditions, selection of the appropriate tissue fragment, and interpretation of the results in the light of microscopical appearance are crucial, providing an integrated molecular pathology report. BRCA1/2 genes have a large size, and many clinically relevant variants have been located throughout the whole coding region of the genes that have to be entirely analyzed. The quality of the DNA from FFPE samples is typically low, and the tumor percentage is variable; thus the variants can be identified at allelic frequencies less than $50 \%$, leading to a complex identification of the variants, compared to peripheral blood samples. For all these reasons, the accurate pipeline validation and the staff experience play an important role in the $B R C A 1 / 2$ genes analysis, which is even more crucial when tumor samples are studied.

\section{Post-analytical Phase II: Variant Interpretation}

Clinical classification should be done following the guidelines developed by the American College of Medical Genetics and Genomics/Association for Molecular Pathology (ACMG/AMP) [5, 27, 54] and the (evidence-based network for the interpretation of germline mutant alleles) ENIGMA consortium [25] (an adaption of the ACMG/AMP rules to the specific case of $B R C A 1 / 2$ ). The ACMG/AMP guidelines propose 28 classification criteria (frequency in control populations, co-segregation, functional data, and in silico predictions, among others), categorize them according to their strength for a benign or pathogenic assertion, and propose rules to combine different criteria into a final five-tier classification of variants that reflects their probabilities of being clinically relevant (see Table 4). 
Table 4 IARC five-tier classification, adapted from [49]. *Based on the recommendations from the EMQN (European Molecular Genetics Quality Network)

\begin{tabular}{|c|c|c|c|c|c|c|}
\hline Class & Probability (quantitative) & Description (qualitative) & Report? & Predictive testing? & Management of carriers & Research testing \\
\hline 5 & $>0.99$ & Definitely pathogenic & Yes & Yes & Full high-risk guidelines & No \\
\hline 4 & $0.95-0.99$ & Likely pathogenic & Yes & Yes & Full high-risk guidelines & May be helpful \\
\hline 3 & $0.05-0.949$ & Uncertain & Yes* & No & $\begin{array}{l}\text { Variant irrelevant to risk assesment } \\
\text { (Manage risk based on family history) }\end{array}$ & May be helpful \\
\hline 2 & $0.001-0.049$ & Likely not pathogenic & No* & No & $\begin{array}{l}\text { Variant irrelevant to risk assesment } \\
\text { (Manage risk based on family history) }\end{array}$ & May be helpful \\
\hline 1 & $<0.001$ & not Pathogenic & No* & No & $\begin{array}{l}\text { Variant irrelevant to risk assesment } \\
\text { (Manage risk based on family history) }\end{array}$ & No \\
\hline
\end{tabular}

Most genetic variants will be readily classified as benign based on allele frequency in control population. Indeed, an allele frequency $\geq 0.01$ in any general continental population dataset of at least 2000-observed alleles is considered a benign stand-alone criterion for a $B R C A 1 / 2$ variant $[5,25]$. There are many databases reporting frequencies $[11,23,24,47,48]$. One of the most widely used database to identify nonpathogenic variants is the Genome Aggregation Database (gnomAD) [11], which contains information about 125,748 exomes and 15,708 genomes from unrelated individuals. Other variants will be readily classified as likely pathogenic, based on its location in a canonical splice site, or pathogenic, based on the generation of a premature termination codon not located in the last exon of the gene (PTC-NMD).

We will focus here on the variants of unknown significance (VUS), which are typically missense or intronic variants. A high proportion of the former VUS in BRCA1/2 has been classified, thanks to international efforts that have allowed compilation of evidences and standardization of classification rules $[5,25,27,28,52,54]$. There are three reputable databases $[1,39,46]$ that compile accurate information on $B R C A 1 / 2$ variants classification based on multiple evidences from different sources combined into a Bayesian model to generate a posterior probability and validated by an expert panel [28]: ClinVar, BRCA Exchange, and BRCA Share. In ClinVar, the classification is reliable only if the "review status" contains three stars, meaning that it has been validated by the ENIGMA [25] expert panel, while BRCA Exchange [1] provides the same classification as ClinVar in a more userfriendly environment and more detailed information [14], including a mobile app that provides reclassification updates on variants of interest. On the other hand, BRCA Share ${ }^{\mathrm{TM}}$ [7] compiles data from 16 academic laboratories performing BRCA1/2 testing in France. It is important to highlight that other databases or levels of curation (e.g., $<3$ stars in ClinVar) might not be reliable. For that reason, variant interpretation requires expertise and should be performed by a specialist, avoiding automatic interpretations.

Most variants remaining of uncertain significance after filtering are rare missense, synonymous, or intronic variants
(MAF < 0.01). If pathogenic, missense variants are often assumed to impact the protein structure/function, but the possibility of the underlying nucleotide change leading to aberrant splicing should not be disregarded [65]. Over 400 in silico tools have been developed to predict the functional impact of missense changes [2], including Align GVGD, PolyPhen, SIFT, and MutationTaster. None of these tools is gene specific, but due to the clinical relevance of BRCA1/2 testing, Align GVGD has been calibrated to predict the probability for any missense change in these two genes to be pathogenic [54].

In silico tools predicting splicing alterations are far more accurate. MaxEntScan has been calibrated to predict the prior probability of any possible substitution in $B R C A 1 / 2$ to be pathogenic due to an impact on splicing [64]. Due to its accuracy, the ENIGMA expert panel has included a specific role for well-calibrated splicing tools in its classification process. More specifically, rare synonymous or intronic variants (IVS + 20_IVS-40 range) not predicted to affect or create splice sites are considered likely benign. By contrast, variants predicted alter splicing cannot be considered automatically pathogenic, distinguishing between spliceogenicity (the variant is altering splicing) and pathogenicity (the splicing alteration is pathogenic). For that reason, in the absence of RNA analysis, variants located in the acceptor site of BRCAl exons $8,9,10,13$, and 14 and $B R C A 2$ exon 12 and variants located in the donor site of BRCAl exons 9 and 10 and $B R C A 2$ exon 12 should be considered VUS. Align GVGD- and MaxEntScan-calibrated predictions are updated periodically [35] and have been incorporated as well into the BRCA Exchange detail view.

\section{Splicing Studies}

The most likely mechanism underlying the pathogenic nature (if any) of synonymous and intronic variants is aberrant splicing. A recent report by the ENIGMA consortium describes some aspects relevant to design, perform, and interpret adequately studies performed by RT-PCR in blood derived RNA from carriers. [67]. If the study demonstrates that the variant 
Table 5 Recommended content information for a proper report of $B R C A 1 / 2$ mutational test

$\begin{array}{ll}\text { - Description of the sample analyzed } & \begin{array}{l}\text { Peripheral blood DNA, DNA from FFPE tissue } \\ \text { - In the case of studies carried out on tumor }\end{array} \\ \text { samples, indicate the suitability of the sample } & \begin{array}{l}\text { Neoplastic content estimation and cellularity, } \\ \text { limit of detection of the test performed } \\ \text { (the percentage of mutated allele that is } \\ \text { detectable with the technique used, } \\ \text { experimentally determined during } \\ \text { the validation process) }\end{array}\end{array}$

Technique

- Description of the analytical determination

- Description of the NGS relevant quality parameters

- Has the analysis of the number of copies of the genes been performed?

- Limitations of the test

- Genes reference sequence number/version

Variants

- Definition of the criteria used to filter out variants
Horizontal extent of the region analyzed, sequencing platform and chemistry used, methodology of enrichment of the genes, steps of bioinformatics pipeline

Global depth of coverage, minimum coverage of all analyzed bases, percentage of bases with a coverage $>30 \mathrm{X}$ ( $500 \mathrm{X}$ in somatic and must be accompanied by the limit of detection of allelic frequency)

YES (by MLPA, NGS, others) or NO

Analytical sensitivity, detection of deep intronic variants or large indels, existence of areas of low coverage, the accurate sequencing of homopolymer regions ( $>8 \mathrm{nt}$ )

Database version for annotation and HGVS (Human Genome Variation Society) nomenclature for cDNA and amino acid changes

Information from databases supporting pathogenicity or the potential therapeutic implications

Recommendations

\footnotetext{
- Negative germline reports should advise a tumor study for the determination of somatic $B R C A 1 / 2$ mutations

- Positive BRCA1/2 somatic reports should recommend a germline study to determine the nature of the mutation identified and its correct interpretation in the personal and family context of cancer

- Reports with positive BRCA1/2 mutation should recommend the referral of the patient to a genetic counseling unit for the purpose of an adequate interpretation of the results and their personal and family implications
}

allele produces only PTC-NMD transcripts and/or transcripts lacking the coding sequence of critical functional domain, it can be classified as pathogenic. If RNA from carriers is not available, or if the splicing outcome observed does not permit a definitive classification, complementary studies performed by validated reporter minigenes might be useful.

\section{Reporting Germline and Somatic BRCA1/2 Results}

The laboratory must determine which variants, according to its clinical significance, are informed and how the results will be communicated. For $B R C A 1 / 2$ genes, there is a broad international consensus to use the five-classes classification [56]. All pathogenic and likely pathogenic variants (classes 5 and 4, respectively) must be informed; reporting of VUS (class 3 ) is recommended, with the statement that it should not be used in a clinical decision-making context.

The report should contain the identification data of the patient and his/her diagnosis, the name of the physician requesting the test, and the reason for referral. Methodology of the diagnostic test performed and its scope should be accurately described (see Table 5). Reports should contain a summary of the results clearly framed and a discussion of the clinical relevance and the limitations of the test. Reports must be signed by at least two qualified faculties who have reviewed, approved and interpreted the results and should clearly identify the laboratory and its contact information, as well as its accreditations-certifications and participation in quality assessments. The report must be clear and concise; one page is the preference for the European Molecular Quality Network (EMQN) [3] and the Genomics Quality Assessment (GenQA) [4]; and two are accepted when reporting NGS results to provide the information specified here (important content information is described in Table 5) $[12,45,60]$ and other information that the laboratory wish to report should be provided as supplementary and clearly separated from the main report. The laboratory must agree with the clinical team and the delivery time of the results; although considering its relevance for certain therapeutic decisions, the laboratory should ensure a fast delivery time in cases that need it. 


\section{Recommendations and Quality Programs}

In order to ensure a correct clinical practice, it is recommended that laboratories have certification and accreditation to perform molecular genetic studies. Certification is defined by ISO as the "Procedure by which a third party gives written assurance that a product, process or service conforms to specific requirements." Certification is performed typically according to the ISO90012015 standard, and, although provides a quality measure, it does not ensure that the laboratory has demonstrate technical competence to produce valid data and results. The requirements of certification address the quality management system (QMS) and include procedures and a quality manual, document control, define non-conformities (NCs) and corrective and preventive actions (CAPA), perform internal audits, and enhance customer satisfaction, but it does not necessarily include requirements of technical or analytical competence.

Accreditation is defined by ISO as the "Procedure by which an authoritative body gives formal recognition that a body or person is competent to carry out specific tasks." The standard developed by ISO most frequently used in medical laboratories is the ISO15189 and ensures technical competence of a laboratory to perform specific types of testing by complying with specific management and technical requirements. The accreditation process also considers the QMS, like certification, but it has additional formal requirements of technical competence, including initial and continuous training of personnel, validation of methods and instruments, as well as internal and external quality control [8]. As a result, certification (typically according to the ISO9001 standard) should not be interpreted to mean that a laboratory has demonstrated the technical competence to produce valid data and results.

There is also a difference in the body that carries out the assessment and delivers the certification or accreditation certificate. Laboratories applying for ISO 9001 certification will be audited by a certification body, a third party that is accredited by an accreditation body. Each country has multiple certification bodies, but there is only one recognized national accreditation body (NAB) in each country that assesses laboratories against internationally agreed standards (Regulation (EC) No 765/2008). In Spain this is Entidad Nacional de Acreditación (ENAC).

As part of the accreditation process, it is mandatory to provide internal quality controls (IQC) and to participate in external quality assessment (EQA). IQC is an internal verification that the test yields consistent results day after day and is defined as "the set of procedures undertaken by the staff of a laboratory for continuously assessing laboratory work and the emergent results, in order to decide whether they are reliable enough to be released" [69]. EQA implies testing of the same samples by different laboratories. This assessment may be done either by cross-validation of samples among laboratories or may be organized by external agencies. In the case of $B R C A 1 / 2$ assessment, this is covered by the quality programs of the EMQN and GENQA.
These programs evaluate not only the technical performance of producing analytical results from samples shared to all participating laboratories but also the accuracy of the report produced (data included from the patients, information regarding testing, accuracy of databases employed), as well as the interpretation of the genetic results. In the case of $B R C A$ assessment, this is of utmost importance as mutational assessment may not only include the detection of pathogenic variants but also VUS or benign variants, which should be correctly identified. For this reason, in recent years, some quality control assessments have been only based in the interpretation of the $B R C A 1 / 2$ variants, without performing wet-lab testing.

\section{Beyond BRCA Testing}

Germline or somatic mutations in HR genes other than BRCA1/2 have been reported in approximately $10 \%$ of ovarian carcinomas, including both serous and non-serous histologies [51, 63]. In addition, it has been observed that mutations in other HR genes have a similar positive impact on OS and platinum responsiveness as BRCA1/2 mutations [51]. Finally, HRD can be assessed by methods other than the analysis of mutations in HRD genes. As a consequence of HRD, typical genomic alterations, such as $\mathrm{LOH}$, telomeric imbalance, and large-scale transitions, can be accumulated and can be measured. Ovarian carcinomas with high LOH $(\geq 14-16 \%)$ determined by NGS showed good response to rucaparib [62]. In addition, LOH, together with telomeric allelic imbalance and large-scale transitions, generates an HRD score (MyChoice ${ }^{\circledR}$ HRD test, Myriad Genetics Inc., Salt Lake City, Utah), which when $\geq 42$ is associated to benefit to olaparib $[34,40]$. In accordance with these data, ESMOESGO consensus conference recommended that testing for mutations in other HR genes, in particular RAD5IC/D, BRIP1, and $P A L B 2$, should be considered in patient with ovarian cancer. Current assays of HR function, although promising, cannot be used to exclude patients from PARP inhibitor therapy [16].

Acknowledgments This project was supported by grants from Instituto Carlos III (ISCIII) (PI15/00059, PI16/00887, PI18/00382, PI16/00563, PI19/00553, and PIE15/00050) and CIBERONC (CB16/12/00316); cofinanced by the European Development Regional Fund, "A way to achieve Europe" (FEDER), by the AECC (AIO-AECC 2016), and by the Government of Catalonia [Pla estratègic de recerca i innovació en salut (PERIS), 2017SGR1282 and 2017SGR496]; and also supported by an unrestricted grant from AstraZeneca.

Contributions JP and JCC planned the organization, wrote, and reviewed the manuscript; $\mathrm{MH}, \mathrm{BB}, \mathrm{IJ}, \mathrm{XM}, \mathrm{CL}, \mathrm{SP}, \mathrm{AO}$, and FR wrote and reviewed the manuscript, and JMRR reviewed and formatted the manuscript.

\section{Compliance with Ethical Standards}

All procedures performed in studies involving human participants were in accordance with the ethical standards of the institutional and/or national research committee and with the 1964 Helsinki declaration and its later 
amendments or comparable ethical standards. For this type of study formal consent is not required.

Conflict of Interest Authors declare no conflict of interest.

Open Access This article is distributed under the terms of the Creative Commons Attribution 4.0 International License (http:// creativecommons.org/licenses/by/4.0/), which permits unrestricted use, distribution, and reproduction in any medium, provided you give appropriate credit to the original author(s) and the source, provide a link to the Creative Commons license, and indicate if changes were made.

\section{References}

1. BRCA Exchange. https://brcaexchange.org/

2. CAGI experiment. https://genomeinterpretation.org/

3. European Molecular Genetics Quality Network. https://www.emqn. org/

4. Genomics Quality Assessment. https://www.genqa.org/

5. Abou Tayoun AN, Pesaran T, DiStefano MT, Oza A, Rehm HL, Biesecker LG, Harrison SM (2018) Recommendations for interpreting the loss of function PVS1 ACMG/AMP variant criterion. Hum Mutat 39:1517-1524. https://doi.org/10.1002/humu. 23626

6. Bai Y, Tolles J, Cheng H, Siddiqui S, Gopinath A, Pectasides E, Camp RL, Rimm DL, Molinaro AM (2011) Quantitative assessment shows loss of antigenic epitopes as a function of pre-analytic variables Lab Invest 91:1253-1261. https://doi.org/10.1038/ labinvest.2011.75

7. Beroud C, Letovsky SI, Braastad CD, Caputo SM, Beaudoux O, Bignon YJ, Bressac-De Paillerets B, Bronner M, Buell CM, Collod-Beroud G, Coulet F, Derive N, Divincenzo C, Elzinga CD, Garrec C, Houdayer C, Karbassi I, Lizard S, Love A, Muller D, Nagan N, Nery CR, Rai G, Revillion F, Salgado D, Sevenet N, Sinilnikova O, Sobol H, Stoppa-Lyonnet D, Toulas C, Trautman E, Vaur D, Vilquin P, Weymouth KS, Willis A, Eisenberg M, Strom CM (2016) BRCA share: a collection of clinical BRCA gene variants. Hum Mutat 37:1318-1328. https://doi.org/10.1002/humu. 23113

8. Berwouts S, Morris MA, Dequeker E (2010) Approaches to quality management and accreditation in a genetic testing laboratory. European journal of human genetics : EJHG 18(Suppl 1):1-19. https://doi.org/10.1038/ejhg.2010.104

9. Besser J, Carleton HA, Gerner-Smidt P, Lindsey RL, Trees E (2018) Next-generation sequencing technologies and their application to the study and control of bacterial infections. Clin Microbiol Infect 24:335-341. https://doi.org/10.1016/j.cmi.2017.10.013

10. Bonin S, Hlubek F, Benhattar J, Denkert C, Dietel M, Fernandez PL, Hofler G, Kothmaier H, Kruslin B, Mazzanti CM, Perren A, Popper H, Scarpa A, Soares P, Stanta G, Groenen PJ (2010) Multicentre validation study of nucleic acids extraction from FFPE tissues. Virchows Arch 457:309-317. https://doi.org/10. 1007/s00428-010-0917-5

11. Broad I The genome aggregation database (gnomAD). https:// gnomad.broadinstitute.org/. Accessed 30 Aug 2019

12. Capoluongo E, Ellison G, Lopez-Guerrero JA, Penault-Llorca F, Ligtenberg MJL, Banerjee S, Singer C, Friedman E, Markiefka B, Schirmacher P, Buttner R, van Asperen CJ, Ray-Coquard I, Endris V, Kamel-Reid S, Percival N, Bryce J, Rothlisberger B, Soong R, de Castro DG (2017) Guidance statement on BRCA1/2 tumor testing in ovarian cancer patients. Semin Oncol 44:187-197. https://doi. org/10.1053/j.seminoncol.2017.08.004
13. Clement K, Farouni R, Bauer DE, Pinello L (2018) AmpUMI: design and analysis of unique molecular identifiers for deep amplicon sequencing. Bioinformatics (Oxford, England) 34:i202i210. https://doi.org/10.1093/bioinformatics/bty264

14. Cline MS, Liao RG, Parsons MT, Paten B, Alquaddoomi F, Antoniou A, Baxter S, Brody L, Cook-Deegan R, Coffin A, Couch FJ, Craft B, Currie R, Dlott CC, Dolman L, den Dunnen JT, Dyke SOM, Domchek SM, Easton D, Fischmann Z, Foulkes WD, Garber J, Goldgar D, Goldman MJ, Goodhand P, Harrison S, Haussler D, Kato K, Knoppers B, Markello C, Nussbaum R, Offit K, Plon SE, Rashbass J, Rehm HL, Robson M, Rubinstein WS, Stoppa-Lyonnet D, Tavtigian S, Thorogood A, Zhang C, Zimmermann M, Burn J, Chanock S, Ratsch G, Spurdle AB (2018) BRCA challenge: BRCA exchange as a global resource for variants in BRCA1 and BRCA2. PLoS Genet 14:e1007752. https://doi.org/10.1371/journal.pgen.1007752

15. Colombo N, Sessa C, du Bois A, Ledermann J, McCluggage WG, McNeish I, Morice P, Pignata S, Ray-Coquard I, Vergote I, Baert T, Belaroussi I, Dashora A, Olbrecht S, Planchamp F, Querleu D (2019) ESMO-ESGO consensus conference recommendations on ovarian cancer: pathology and molecular biology, early and advanced stages, borderline tumours and recurrent diseasedagger Ann Oncol 30:672-705. https://doi.org/10.1093/annonc/mdz062

16. Colombo N, Sessa C, du Bois A, Ledermann J, McCluggage WG, McNeish I, Morice P, Pignata S, Ray-Coquard I, Vergote I, Baert T, Belaroussi I, Dashora A, Olbrecht S, Planchamp F, Querleu D, Group E-EOCCCW (2019) ESMO-ESGO consensus conference recommendations on ovarian cancer: Pathology and molecular biology, early and advanced stages, borderline tumours and recurrent diseasedagger. Ann Oncol 30:672-705. https://doi.org/10.1093/ annonc/mdz062

17. Compton CC, Robb JA, Anderson MW, Berry AB, Birdsong GG, Bloom KJ, Branton PA, Crothers JW, Cushman-Vokoun AM, Hicks DG, Khoury JD, Laser J, Marshall CB, Misialek MJ, Natale KE, Nowak JA, Olson D, Pfeifer JD, Schade A, Vance GH, Walk EE, Yohe SL (2019) Preanalytics and precision pathology: pathology practices to ensure molecular integrity of cancer patient biospecimens for precision medicine. Arch Pathol Lab Med. https://doi.org/10.5858/arpa.2019-0009-SA

18. de Jong D, Verbeke S, Meijer D, Hogendoorn PC, Bovee JV, Szuhai $\mathrm{K}$ (2011) Opening the archives for state of the art tumour genetic research: sample processing for array-CGH using decalcified, formalin-fixed, paraffin-embedded tissue-derived DNA samples. BMC Res Notes 4:1. https://doi.org/10.1186/1756-0500-4-1

19. de Jonge MM, Ruano D, van Eijk R, van der Stoep N, Nielsen M, Wijnen JT, Ter Haar NT, Baalbergen A, Bos M, Kagie MJ, Vreeswijk MPG, Gaarenstroom KN, Kroep JR, Smit V, Bosse T, van Wezel T, van Asperen CJ (2018) Validation and implementation of BRCA1/2 variant screening in ovarian tumor tissue. The Journal of molecular diagnostics : JMD 20:600-611. https://doi. org/10.1016/j.jmoldx.2018.05.005

20. Dietrich D, Uhl B, Sailer V, Holmes EE, Jung M, Meller S, Kristiansen G (2013) Improved PCR performance using template DNA from formalin-fixed and paraffin-embedded tissues by overcoming PCR inhibition. PLoS One 8:e77771. https://doi.org/10. 1371/journal.pone.0077771

21. Dijkstra JR, Heideman DA, Meijer GA, Boers JE, NA t H, Diebold J, Hirschmann A, Hoefler G, Winter G, Miltenberger-Miltenyi G, Pereira SV, Richman SD, Quirke P, Rouleau EL, Guinebretiere JM, Tejpar S, Biesmans B, van Krieken JH (2013) KRAS mutation analysis on low percentage of colon cancer cells: The importance of quality assurance. Virchows Arch 462:39-46. https://doi.org/10. 1007/s00428-012-1356-2

22. Do H, Dobrovic A (2015) Sequence artifacts in DNA from formalin-fixed tissues: causes and strategies for minimization. 
Clin Chem 61:64-71. https://doi.org/10.1373/clinchem.2014. 223040

23. EMBI-EBI (2000) Ensembl Project. http://www.ensembl.org/ index.html. Accessed 30 Aug 2019

24. EMBL-EBI (2008) IGSR: The International Genome Sample Resource. http://www.1000genomes.org/. Accessed 30 Aug 2019

25. ENIGMA C (2016) Evidence-based network for the interpretation of germline mutant alleles (ENIGMA). http://enigmaconsortium. org/. Accessed 30 Aug 2019

26. Feliubadalo L, Lopez-Doriga A, Castellsague E, del Valle J, Menendez M, Tornero E, Montes E, Cuesta R, Gomez C, Campos O, Pineda M, Gonzalez S, Moreno V, Brunet J, Blanco I, Serra E, Capella G, Lazaro C (2013) Next-generation sequencing meets genetic diagnostics: development of a comprehensive workflow for the analysis of BRCA1 and BRCA2 genes. European journal of human genetics : EJHG 21:864-870. https:// doi.org/10.1038/ejhg.2012.270

27. Ghosh R, Harrison SM, Rehm HL, Plon SE, Biesecker LG (2018) Updated recommendation for the benign stand-alone ACMG/AMP criterion. Hum Mutat 39:1525-1530. https://doi.org/10.1002/ humu. 23642

28. Goldgar DE, Easton DF, Byrnes GB, Spurdle AB, Iversen ES (2008) Greenblatt MS. Genetic evidence and integration of various data sources for classifying uncertain variants into a single model Hum Mutat 29:1265-1272. https://doi.org/10.1002/humu.20897

29. Goldstein NS, Hewitt SM, Taylor CR, Yaziji H, Hicks DG, Members of Ad-Hoc Committee on Immunohistochemistry S (2007) Recommendations for improved standardization of immunohistochemistry. Appl Immunohistochem Mol Morphol 15:124 133. https://doi.org/10.1097/PAI.0b013e31804c7283

30. Goodwin S, McPherson JD, WR MC (2016) Coming of age: ten years of next-generation sequencing technologies. Nat Rev Genet 17:333-351. https://doi.org/10.1038/nrg.2016.49

31. Gori S, Barberis M, Bella MA, Buttitta F, Capoluongo E, Carrera P, Colombo N, Cortesi L, Genuardi M, Gion M, Guarneri V, Incorvaia L, La Verde N, Lorusso D, Marchetti A, Marchetti P, Normanno N, Pasini B, Pensabene M, Pignata S, Radice P, Ricevuto E, Sapino A, Tagliaferri P, Tassone P, Trevisiol C, Truini M, Varesco L, Russo A (2019) Recommendations for the implementation of BRCA testing in ovarian cancer patients and their relatives. Crit Rev Oncol Hematol:140, 67-172. https://doi.org/10.1016/j.critrevonc.2019. 05.012

32. Head SR, Komori HK, LaMere SA, Whisenant T, Van Nieuwerburgh F, Salomon DR, Ordoukhanian P (2014) Library construction for next-generation sequencing: overviews and challenges. Biotechniques 56:61-64, 66, 68, passim. https://doi.org/10. 2144/000114133

33. Hicks DG, Boyce BF (2012) The challenge and importance of standardizing pre-analytical variables in surgical pathology specimens for clinical care and translational research. Biotech Histochem 87:14-17. https://doi.org/10.3109/10520295.2011.591832

34. Hodgson DR, Dougherty BA, Lai Z, Fielding A, Grinsted L, Spencer S, O'Connor MJ, Ho TW, Robertson JD, Lanchbury JS, Timms KM, Gutin A, Orr M, Jones H, Gilks B, Womack C, Gourley C, Ledermann J, Barrett JC (2018) Candidate biomarkers of PARP inhibitor sensitivity in ovarian cancer beyond the BRCA genes. Br J Cancer 119:1401-1409. https://doi.org/10.1038/ s41416-018-0274-8

35. Huntsman CI (2000) HCI breast cancer genes prior probabilities. http://priors.hci.utah.edu/PRIORS/BRCA/

36. Kang Q, Henry NL, Paoletti C, Jiang H, Vats P, Chinnaiyan AM, Hayes DF, Merajver SD, Rae JM, Tewari M (2016) Comparative analysis of circulating tumor DNA stability In K3EDTA, Streck, and CellSave blood collection tubes. Clin Biochem 49:1354-1360. https://doi.org/10.1016/j.clinbiochem.2016.03.012
37. Kchouk M, Gibrat J-F, Elloumi M (2017) Generations of sequencing technologies: from first to next generation.

38. Kerkhof J, Schenkel LC, Reilly J, McRobbie S, Aref-Eshghi E, Stuart A, Rupar CA, Adams P, Hegele RA, Lin H, Rodenhiser D, Knoll J, Ainsworth PJ, Sadikovic B (2017) Clinical validation of copy number variant detection from targeted next-generation sequencing panels. The Journal of molecular diagnostics : JMD 19: 905-920. https://doi.org/10.1016/j.jmoldx.2017.07.004

39. LabCorp, UNICANCER (2016) BRCA Share. http://www.umd.be/ BRCA1/

40. Lheureux S, Lai Z, Dougherty BA, Runswick S, Hodgson DR, Timms KM, Lanchbury JS, Kaye S, Gourley C, Bowtell D, Kohn EC, Scott C, Matulonis U, Panzarella T, Karakasis K, Burnier JV, Gilks CB, O'Connor MJ, Robertson JD, Ledermann J, Barrett JC, Ho TW, Oza AM (2017) Long-term responders on olaparib maintenance in high-grade serous ovarian cancer: Clinical and molecular characterization. Clin Cancer Res 23:4086-4094. https://doi.org/ 10.1158/1078-0432.CCR-16-2615

41. Li MM, Datto M, Duncavage EJ, Kulkarni S, Lindeman NI, Roy S, Tsimberidou AM, Vnencak-Jones CL, Wolff DJ, Younes A, Nikiforova MN (2017) Standards and guidelines for the interpretation and reporting of sequence variants in cancer: a joint consensus recommendation of the Association for Molecular Pathology. J Mol Diagnostics 19:4-23. https://doi.org/10.1016/j.jmoldx.2016.10.002

42. Malentacchi F, Ciniselli CM, Pazzagli M, Verderio P, Barraud L, Hartmann CC, Pizzamiglio S, Weisbuch S, Wyrich R, Gelmini S (2015) Influence of pre-analytical procedures on genomic DNA integrity in blood samples: The SPIDIA experience. Clin Chim Acta 440:205-210. https://doi.org/10.1016/j.cca.2014.12.004

43. Malentacchi F, Pazzagli M, Simi L, Orlando C, Wyrich R, Hartmann CC, Verderio P, Pizzamiglio S, Ciniselli CM, Tichopad A, Kubista M, Gelmini S (2013) SPIDIA-DNA: an external quality assessment for the pre-analytical phase of blood samples used for DNA-based analyses. Clin Chim Acta 424:274-286. https://doi. org/10.1016/j.cca.2013.05.012

44. Marsden J, Hamoda H (2019) European cancer mortality predictions for the year 2019 with focus on breast cancer, by Malvezzi M et al. (Ann Oncol 2019; 30: doi.org/10.1093/annonc/mdz051) Ann Oncol. doi: https://doi.org/10.1093/annonc/mdz144

45. Matthijs G, Souche E, Alders M, Corveleyn A, Eck S, Feenstra I, Race V, Sistermans E, Sturm M, Weiss M, Yntema H, Bakker E, Scheffer H, Bauer P, EuroGentest, European Society of Human Genetics (2016) Guidelines for diagnostic next-generation sequencing. Eur. J. Hum. Genet 24(1):2-5 https://doi.org/10.1038/ejhg. 2015.226

46. NCBI ClinVar. https://www.ncbi.nlm.nih.gov/clinvar/

47. NCBI dbSNP. http://www.ncbi.nlm.nih.gov/SNP/

48. NHLBI NHLBI Grand opportunity exome sequencing project (ESP). http://evs.gs.washington.edu/EVS/

49. Oaknin A, Guarch R, Barretina P, Hardisson D, Gonzalez-Martin A, Matias-Guiu X, Perez-Fidalgo A, Vieites B, Romero I, Palacios J (2018) Recommendations for biomarker testing in epithelial ovarian cancer. A national consensus statement by the Spanish Society of Pathology and the Spanish Society of Medical Oncology. Revista espanola de patologia : publicacion oficial de la Sociedad Espanola de Anatomia Patologica y de la Sociedad Espanola de Citologia 51: 84-96. https://doi.org/10.1016/j.patol.2017.11.002

50. Pabinger S, Dander A, Fischer M, Snajder R, Sperk M, Efremova M, Krabichler B, Speicher MR, Zschocke J, Trajanoski Z (2014) A survey of tools for variant analysis of next-generation genome sequencing data. Brief Bioinform 15:256-278. https://doi.org/10. 1093/bib/bbs086

51. Pennington KP, Walsh T, Harrell MI, Lee MK, Pennil CC, Rendi $\mathrm{MH}$, Thornton A, Norquist BM, Casadei S, Nord AS, Agnew KJ, Pritchard CC, Scroggins S, Garcia RL, King MC, Swisher EM (2014) Germline and somatic mutations in homologous 
recombination genes predict platinum response and survival in ovarian, fallopian tube, and peritoneal carcinomas. Clin Cancer Res 20:764-775. https://doi.org/10.1158/1078-0432.CCR-13-2287

52. Plon SE, Eccles DM, Easton D, Foulkes WD, Genuardi M, Greenblatt MS, Hogervorst FB, Hoogerbrugge N, Spurdle AB, Tavtigian SV (2008) Sequence variant classification and reporting: recommendations for improving the interpretation of cancer susceptibility genetic test results. Hum Mutat 29:1282-1291. https:// doi.org/10.1002/humu.20880

53. Prat J, D'Angelo E, Espinosa I (2018) Ovarian carcinomas: at least five different diseases with distinct histological features and molecular genetics. Hum Pathol 80:11-27. https://doi.org/10.1016/j. humpath.2018.06.018

54. Richards S, Aziz N, Bale S, Bick D, Das S, Gastier-Foster J, Grody WW, Hegde M, Lyon E, Spector E, Voelkerding K, Rehm HL (2015) Standards and guidelines for the interpretation of sequence variants: a joint consensus recommendation of the American College of Medical Genetics and Genomics and the Association for Molecular Pathology. Genet. Med 17:405-424. https://doi.org/ 10.1038/gim.2015.30

55. Roy S, Coldren C, Karunamurthy A, Kip NS, Klee EW, Lincoln SE, Leon A, Pullambhatla M, Temple-Smolkin RL, Voelkerding KV, Wang C, Carter AB (2018) Standards and guidelines for validating next-Generation sequencing bioinformatics pipelines: a joint recommendation of the Association for Molecular Pathology and the College of American Pathologists. The Journal of molecular diagnostics : JMD 20:4-27. https://doi.org/10.1016/j.jmoldx.2017. 11.003

56. Samorodnitsky E, Jewell BM, Hagopian R, Miya J, Wing MR, Lyon E, Damodaran S, Bhatt D, Reeser JW, Datta J, Roychowdhury S (2015) Evaluation of hybridization capture versus amplicon-based methods for whole-exome sequencing. Hum Mutat 36:903-914. https://doi.org/10.1002/humu.22825

57. Schuurbiers OC, Looijen-Salamon MG, Ligtenberg MJ, van der Heijden HF (2010) A brief retrospective report on the feasibility of epidermal growth factor receptor and KRAS mutation analysis in transesophageal ultrasound- and endobronchial ultrasound-guided fine needle cytological aspirates. J Thorac Oncol 5:1664-1667. https://doi.org/10.1097/JTO.0b013e3181f0bd93

58. Singh RR, Luthra R, Routbort MJ, Patel KP, Medeiros LJ (2016) Implementation of next generation sequencing in clinical molecular diagnostic laboratories: advantages, challenges and potential. Expert Rev. Precis. Med. Drug Dev. 1:109-120https://doi.org/10. 1080/23808993.2015.1120401

59. Singh VM, Salunga RC, Huang VJ, Tran Y, Erlander M, Plumlee P, Peterson MR (2013) Analysis of the effect of various decalcification agents on the quantity and quality of nucleic acid (DNA and RNA) recovered from bone biopsies. Ann Diagn Pathol 17:322326. https://doi.org/10.1016/j.anndiagpath.2013.02.001

60. Soto JL, Blanco I, Diez O, Garcia Planells J, Lorda I, Matthijs G, Robledo M, Souche E, Lazaro C (2018) Consensus document on the implementation of next generation sequencing in the genetic diagnosis of hereditary cancer. Med Clin (Barc) 151(80):e81-80 e10. https://doi.org/10.1016/j.medcli.2017.12.010

61. Sun PL, Jin Y, Kim H, Lee CT, Jheon S, Chung JH (2013) High concordance of EGFR mutation status between histologic and corresponding cytologic specimens of lung adenocarcinomas. Cancer Cytopathol 121:311-319. https://doi.org/10.1002/cncy.21260

62. Swisher EM, Lin KK, Oza AM, Scott CL, Giordano H, Sun J, Konecny GE, Coleman RL, Tinker AV, O'Malley DM, Kristeleit RS, Ma L, Bell-McGuinn KM, Brenton JD, Cragun JM, Oaknin A, Ray-Coquard I, Harrell MI, Mann E, Kaufmann SH, Floquet A, Leary A, Harding TC, Goble S, Maloney L, Isaacson J, Allen AR, Rolfe L, Yelensky R, Raponi M, McNeish IA (2017) Rucaparib in relapsed, platinum-sensitive high-grade ovarian carcinoma (ARIEL2 Part 1): an international, multicentre, open-label, phase 2 trial. Lancet Oncol 18:75-87. https://doi.org/10.1016/ S1470-2045(16)30559-9

63. The Cancer Genome Atlas Research N, Bell D, Berchuck A, Birrer M, Chien J, Cramer DW, Dao F, Dhir R, DiSaia P, Gabra H, Glenn P, Godwin AK, Gross J, Hartmann L, Huang M, Huntsman DG, Iacocca M, Imielinski M, Kalloger S, Karlan BY, Levine DA, Mills GB, Morrison C, Mutch D, Olvera N, Orsulic S, Park K, Petrelli N, Rabeno B, Rader JS, Sikic BI, Smith-McCune K, Sood AK, Bowtell D, Penny R, Testa JR, Chang K, Creighton CJ, Dinh HH, Drummond JA, Fowler G, Gunaratne P, Hawes AC, Kovar CL, Lewis LR, Morgan MB, Newsham IF, Santibanez J, Reid JG, Trevino LR, Wu YQ, Wang M, Muzny DM, Wheeler DA, Gibbs RA, Getz G, Lawrence MS, Cibulskis K, Sivachenko AY, Sougnez C, Voet D, Wilkinson J, Bloom T, Ardlie K, Fennell T, Baldwin J, Nichol R, Fisher S, Gabriel S, Lander ES, Ding L, Fulton RS, Koboldt DC, McLellan MD, Wylie T, Walker J, O'Laughlin M, Dooling DJ, Fulton L, Abbott R, Dees ND, Zhang Q, Kandoth C, Wendl M, Schierding W, Shen D, Harris CC, Schmidt H, Kalicki J, Delehaunty KD, Fronick CC, Demeter R, Cook L, Wallis JW, Lin L, Magrini VJ, Hodges JS, Eldred JM, Smith SM, Pohl CS, Vandin F, Upfal E, Raphael BJ, Weinstock GM, Mardis ER, Wilson RK, Meyerson M, Winckler W, Getz G, Verhaak RGW, Carter SL, Mermel CH, Saksena G, Nguyen H, Onofrio RC, Lawrence MS, Hubbard D, Gupta S, Crenshaw A, Ramos AH, Ardlie K, Chin L, Protopopov A, Zhang J, Kim TM, Perna I, Xiao Y, Zhang H, Ren G, Sathiamoorthy N, Park RW, Lee E, Park PJ, Kucherlapati R, Absher DM, Waite L, Sherlock G, Brooks JD, Li JZ, Xu J, Myers RM, Laird PW, Cope L, Herman JG, Shen H, Weisenberger DJ, Noushmehr H, Pan F, Triche T Jr, Berman BP, Van Den Berg DJ, Buckley J, Baylin SB, Spellman PT, Purdom E, Neuvial P, Bengtsson H, Jakkula LR, Durinck S, Han J, Dorton S, Marr H, Choi YG, Wang V, Wang NJ, Ngai J, Conboy JG, Parvin B, Feiler HS, Speed TP, Gray JW, Levine DA, Socci ND, Liang Y, Taylor BS, Schultz N, Borsu L, Lash AE, Brennan C, Viale A, Sander C, Ladanyi M, Hoadley KA, Meng S, Du Y, Shi Y, Li L, Turman YJ, Zang D, Helms EB, Balu S, Zhou X, Wu J, Topal MD, Hayes DN, Perou CM, Getz G, Voet D, Saksena G, Zhang J, Zhang H, Wu CJ, Shukla S, Cibulskis K, Lawrence MS, Sivachenko A, Jing R, Park RW, Liu Y, Park PJ, Noble M, Chin L, Carter H, Kim D, Samayoa J, Karchin R, Spellman PT, Purdom E, Neuvial P, Bengtsson H, Durinck S, Han J, Korkola JE, Heiser LM, Cho RJ, Hu Z, Parvin B, Speed TP, Gray JW, Schultz N, Cerami E, Taylor BS, Olshen A, Reva B, Antipin Y, Shen R, Mankoo P, Sheridan R, Ciriello G, Chang WK, Bernanke JA, Borsu L, Levine DA, Ladanyi M, Sander C, Haussler D, Benz CC, Stuart JM, Benz SC, Sanborn JZ, Vaske CJ, Zhu J, Szeto C, Scott GK, Yau C, Hoadley KA, Du Y, Balu S, Hayes DN, Perou CM, Wilkerson MD, Zhang N, Akbani R, Baggerly KA, Yung WK, Mills GB, Weinstein JN, Penny R, Shelton T, Grimm D, Hatfield M, Morris S, Yena P, Rhodes P, Sherman M, Paulauskis J, Millis S, Kahn A, Greene JM, Sfeir R, Jensen MA, Chen J, Whitmore J, Alonso S, Jordan J, Chu A, Zhang J, Barker A, Compton C, Eley G, Ferguson M, Fielding P, Gerhard DS, Myles R, Schaefer C, Mills Shaw KR, Vaught J, Vockley JG, Good PJ, Guyer MS, Ozenberger B, Peterson J, Thomson E (2011) Integrated genomic analyses of ovarian carcinoma. Nature 474:609. https://doi.org/10.1038/nature10166https://www.nature.com/ articles/nature10166\#supplementary-information. Accessed 30 Aug 2019

64. Vallee MP, Di Sera TL, Nix DA, Paquette AM, Parsons MT, Bell R, Hoffman A, Hogervorst FB, Goldgar DE, Spurdle AB, Tavtigian SV (2016) Adding in silico assessment of potential splice aberration to the integrated evaluation of BRCA gene unclassified variants. Hum Mutat 37:627-639. https://doi.org/10.1002/humu.22973

65. Vega A, Campos B, Bressac-De-Paillerets B, Bond PM, Janin N, Douglas FS, Domenech M, Baena M, Pericay C, Alonso C, Carracedo A, Baiget M, Diez O (2001) The R71G BRCA1 is a 
founder Spanish mutation and leads to aberrant splicing of the transcript. Hum Mutat 17:520-521. https://doi.org/10.1002/humu.1136

66. Vergote I, Banerjee S, Gerdes AM, van Asperen C, Marth C, Vaz F, Ray-Coquard I, Stoppa-Lyonnet D, Gonzalez-Martin A, Sehouli J, Colombo N (2016) Current perspectives on recommendations for BRCA genetic testing in ovarian cancer patients. Eur J Cancer 69: 127-134. https://doi.org/10.1016/j.ejca.2016.10.006

67. Whiley PJ, de la Hoya M, Thomassen M, Becker A, Brandao R, Pedersen IS, Montagna M, Menendez M, Quiles F, GutierrezEnriquez S, De Leeneer K, Tenes A, Montalban G, Tserpelis D, Yoshimatsu T, Tirapo C, Raponi M, Caldes T, Blanco A, Santamarina M, Guidugli L, de Garibay GR, Wong M, Tancredi M, Fachal L, Ding YC, Kruse T, Lattimore V, Kwong A, Chan TL, Colombo M, De Vecchi G, Caligo M, Baralle D, Lazaro C, Couch F, Radice P, Southey MC, Neuhausen S, Houdayer C, Fackenthal J, Hansen TV, Vega A, Diez O, Blok R, Claes K, Wappenschmidt B, Walker L, Spurdle AB, Brown MA (2014) Comparison of mRNA splicing assay protocols across multiple laboratories: recommendations for best practice in standardized clinical testing Clin Chem 60: 341-352. doi: https://doi.org/10.1373/clinchem.2013.210658

68. Wickham CL, Boyce M, Joyner MV, Sarsfield P, Wilkins BS, Jones DB, Ellard S (2000) Amplification of PCR products in excess of 600 base pairs using DNA extracted from decalcified, paraffin wax embedded bone marrow trephine biopsies Mol Pathol 53:19-23

69. World Health O, Working group on quality assurance of health $\mathrm{L}$ external quality assessment of health laboratories: report on a WHO working group, Brussels, 4-7 December 1979. Regional Office for Europe, World Health Organization; WHO Publications Centre USA [distributor], Copenhagen; Albany, N.Y., pp.

Publisher's note Springer Nature remains neutral with regard to jurisdictional claims in published maps and institutional affiliations. 